\title{
Reading the near-death experience from an African perspective
}

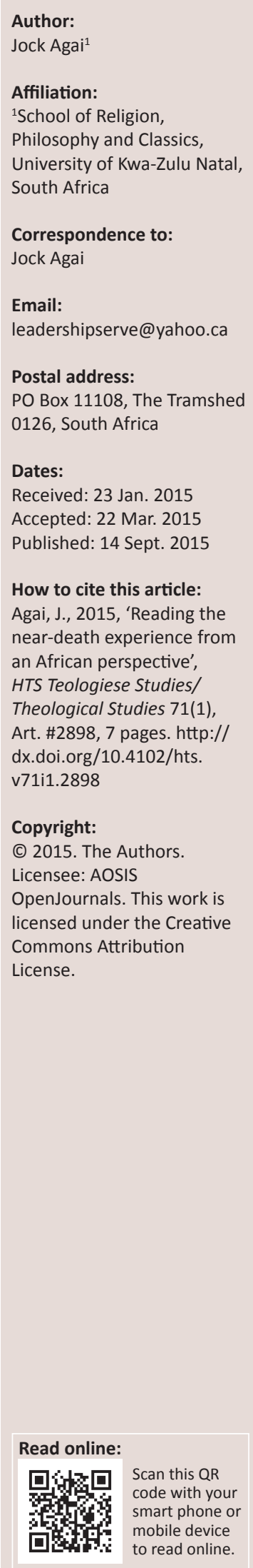

The scientific study of near-death experience (NDE) teaches that NDE does not entail evidence for life after death, but a study of NDE from an African perspective implies that NDE could serve as a yardstick which supports African traditional beliefs concerning death and resurrection. Using references from Ancient-Egyptian afterlife beliefs and those of the Yorubas of Nigeria, I argue that, for Africans, the percipients of NDE did not only come close to death but are regarded as having truly died. The purpose of this research is to initiate an African debate on the subject and to provide background-knowledge about NDE in Africa for counsellors who counsel NDE percipients that are Africans.

\section{Introduction}

Africans are generally regarded as great proponents of afterlife belief. Evidence of ancient afterlife practices found in Egypt suggests that Africa's role in the practice and spread of afterlife beliefs deserve a serious recognition (Turner 1993:12). The elaborate burial practices of the ancient Egyptians, which led to the availability of much evidence concerning the AncientEgyptian afterlife beliefs, have led some scholars to think that afterlife beliefs originated in Egypt (James 1976:156-157; Murnane 1992:37-46; Otey 2004:1-4). For example, Herodotus taught that the ancient Egyptians were the first people to assert that man is immortal and would live after death and that when the body perishes it enters into animals, 'constantly springing into existence' (originally from Herodotus, Edition Bohn, II, 123; Lucas 1948:263). Remains of food-offerings to the dead found in some Canaanites graves together with evidence for the practice of the Cult of Osiris found in Byblos have also caused some scholars (Albright and Koenig are of this opinion - Spronk 1986:57) to believe that those practices were strictly of Egyptian origin. Furthermore, there are many similarities between the ancient Egyptian and Yoruba afterlife beliefs, and these similarities have caused a number of writers to think that the ancient Egyptians were responsible for influencing or originating the Yoruba afterlife beliefs (Johnson 2001:5-7; Umoh 1971:116; cf. Agai 2013:10-12). I am aware that some Western biblical scholars have made several attempts to declassify Egypt as a part of modern Africa. This research is done with the assumption that Egypt was and is a part of the African continent (Adamo 2013:73).

Since the Society for Psychical Research was founded in London and in the USA in 1882, scientific experimentation or studies on psychical experiences and psychobiology have been improving immensely. Unlike in the past, many more scientists are now interested in researching psychical topics such as telepathy, precognition, psychokinesis, mediums, hypnosis, trance and other extra-sensory perceptions (Grosso 1989:237-239; Small 1977:99-100). The study of these kinds of topic has advanced the debate on the mind and brain or mind and body psychology, and this psychology is relevant in the scientific study of the after-life beliefs. Some scientists argue that the mind survives bodily death, but others object to this argument due to insufficient or lack of evidence (Harpur 1991:98; Ma'SU'mian 1996:138; Trueblood 1963:137). The neardeath experience (NDE) in particularly is a topic which promotes the study of connections between the brain and mind or mind and body. Whilst this is relevant in psychology, it is also pertinent to note that, before the emergence of psychology as a formal subject, Africans had and still have their views concerning the activities of these various body components. I explore such conceptions with a view to find means through which the topic of near-death experience could be conceptualised in African culture and in African societies. I hope to achieve this by an explanation of the African views on death and the after-life in comparison to the scientific conception of death. According to the resources used in this research, it is evident that nothing or very little has been done by scholars to define the NDE from African perspectives, hence the need to begin to address the topic. Using the ancient Egyptian and Yoruba conceptions of the use of the various parts of the human body, I propose that scientific and African beliefs concerning the NDE are not the same. 
Daniel Ekechukwu died through injuries he sustained in a fatal car accident on 30 November 2001 in Owerri in southeast Nigeria. Two different medical practitioners confirmed him dead, and his corpse was taken to the mortuary where a mortician applied the necessary chemicals to be embalmed. Daniel's wife insisted that her husband's dead body be taken out of the mortuary to a Christian crusade ground where the popular German Evangelist Reinhardt Bonnke was preaching with thousands of his followers listening. The deceased body was kept in another room in the crusade venue so as not to distract the attention of the huge audience on the crusade ground. Whilst the evangelist was praying for the entire audience, to the surprise of many, Daniel's corpse shivered and was raised to life whilst the injuries on his body disappeared immediately. Daniel claimed that, during his 48 hours of near-death experience, he came across hell, heaven, people he knew, beautiful edifices and angels (De Ruiter 2001).

Similarly, Augustine Chidozie, a renowned evangelist in Nigeria, also believes that he had once died but returned to life. In 2003, he spoke about his death experience in a Pentecostal Church in Bukuru in north-central Nigeria. Chidozie believes that he had truly died because the medical doctors who attended to him certified him dead, but he came back to life after three days. Chidozie claims that he was taken up to heaven where he met with Jesus and other saints. However, he was told that it was not yet his time, hence he had to return to the world to preach the Gospel of Christ to people. I had personally met with Augustine Chidozie and with many other people in Africa who claim that they have had an experience of death. One of them, a blind man living in Jos (north-central Nigeria), said that, whilst in heaven, he never saw any of his physical deformities and that his eyes were not blind. He also claimed that he saw Jesus, the angels and other biblical saints. In today's language, the experiences of Daniel, Augustine and many others who have had similar experiences are referred to as a near-death experience, and it is a universal phenomenon. Yet in Africa, the phenomenon has not been recorded and researched formally as it has been in Europe and in America.

A proper understanding of the meaning of death is required for understanding NDE, and in Africa where it seems that death and life are inseparable, it would have been an advantage to our knowledge if NDE could be studied from an African point of view. At present, the study of NDE is more advanced in medical sciences and in psychology than in theology and anthropology (Fox 2003:62-63). Opening up the study of NDE from another perspective such as religion and anthropology can break the scientific monopoly of knowledge over this interesting subject, and it would allow for a wider view of the subject such that both anthropologists and scientists stand the chance to benefit:

The medical explanations have a fixed, menacing, and unassailable quality, especially for those who feel that the explanations are too reductionist or overzealous. Medical science explanations [even in explaining NDE] appear 'hard', that is, difficult to understand and more objective than social or philosophical explanations. That stereotype hides many recent insights in the sociology of knowledge and in the history and philosophy of science. (Kellehear 1996:5)

The "hard sciences" monopoly of knowledge in the study of NDE is one of the reasons why NDE should be studied from a theological point of view as well. Hampe (1979:33-48) and Fox (2003:59) have done much work in this regard. The study of NDE from an African perspective would allow for the following:

- a formal study of the NDE in Africa, helping to motivate the formal recording and storing of information concerning NDE percipients in Africa

- an analytical study of African beliefs concerning death and the afterlife in comparison to the study of NDE

- the opportunity for Africans to develop their own independent or indigenous knowledge of how NDE can be approached from the perspectives of their cultural or religious backgrounds

- counsellors of percipients of NDE or of their loved ones in Africa to counsel with a proper understanding of how Africans may view NDE.

\section{The scientific perspective on death}

In medical science, the word dying signifies the process of death, and a dying person can be resuscitated. One of the strands of death (somatic death) teaches that death means the absence of life characterised by the complete malfunctioning of vital body organs such as the lungs, the heart and the liver. Somatic death can be caused by sustained injuries, accident, internal illness and even old age. A very important organ that helps to sustain life is the heart. Whenever the heart stops beating for any reason, blood will not be able to circulate through the body, and the oxygen supplied to the brain through blood circulation will no longer be available as a result. This oxygen is what the brain needs most, and the absence thereof causes the brain cells to begin to die through a process called necrosis. The last cells that might survive for some time before finally dying are the hair and nail cells. The body cells that are in the process of dying have the tendency to survive for about four to six minutes before they die finally, and when this happens, such person could be declared clinically dead (Halsey \& Johnston 1989:758).

Furthermore, it is appropriate to note that clinical death occurs when the heart and lungs cease to function, yet, before the cells finally die, immediate restoration or resuscitation could be achieved by restarting the breathing and heartbeat through electric shock, heart massage and other medical techniques. However, more than six minutes after clinical death, resuscitation is often difficult and sometimes impossible. When a person is dead, the body temperature of the deceased gradually drops to the temperature of the environment thus causing the blood to begin to settle down in the lower parts of the body. Within a short period of time, the corpse experiences a state known as rigor mortis, meaning that the body muscles become rigid, that all body tissues 
become vulnerable to attack by bacteria and that the body begins to decompose as a result (Halsey \& Johnston 1989:758).

In the past, medical practitioners regarded a lack of heartbeat as the ultimate criterion for certifying death. This lack can be determined by means of electrocardiographic (EKG) tracing. However, brain impulses, determined by means of the process of electroencephalographic tracing (EEG), are today regarded as the ultimate criterion for certifying death. Brain death occurs when there have been no electrical impulses in the brain for about 24 hours. At present, there is no medical technique for resuscitating a brain that has had no electrical impulses for more than 24 hours, hence a person whose brain cells are dead could be declared medically dead as well (Moody 1975:196-199). Contrary to the medical criterion for certifying death as discussed, Moody (1975:196-199) argues that there are people or percipients whose EKG or EEG tracings ran negative or flat, and yet, they were resuscitated. Moody believes that EEG and EKG tracings have little or nothing to do with the events and experiences of what he terms near death. In summary, death could generally mean one, two or all of the following:

- the absence of functioning vital body organs, particularly when the heart has stopped beating for an extended period of time, which is characterised by a drop in temperature that leads to the eyes opening (Moody 1975:197-200)

- the absence of electrical impulses in the brain (Moody 1975:197-200)

- damage of vital body functions and organs such that the dead cannot come back or return to life (Moody 1975: 197-200).

\section{The African perspective on death}

Ancient Africans had their ways of expressing their beliefs and their technology, and these were not written up until in modern times (Parrinder 1967:12-13). This implies that records stating the criteria used by ancient Africans to certify death are rare or unknown, and as a result, Africans rely on carefully handed-down myths about certain cultural practices together with artefacts and other information often found in burial tombs to understand the African perspective on death. At present, there is no record, despite mummification in ancient Egypt, that any deceased had ever returned to life to share his or her death experience. The same holds true for the Yoruba, who remove the heart of a deceased king to be eaten by the king's successor as a burial process (Lucas 1948:252-253). Ancient Egyptians also removed the heart of a deceased to be stored in canopic jars (Otey 2004:1). As a result, it can be suggested that, before Africans began to document events, death was certified when vital body organs ceased to function or when the deceased's physical body failed to operate in exactly the same way as before death or when the deceased failed to return to life for a long period of time (say from three or seven days and above) whilst the bereaved prepared for his or her burial (most Africans take a minimum period of three to seven days to prepare for a deceased's funeral).
In other contexts, the EEG and EKG tracings are the final yardsticks in certifying death in medical science, and when the physical body has been certified dead, the role of medical science ends, and it has nothing to do with what happens to the deceased in the after-life. Certain body organs may be removed for research or for use to support other lives, but this marks the end of the deceased. This is not the case in the African tradition. To an African, death means a transition from one level of existence to a supreme (ancestral) level of existence, particularly when burial rites are observed or when the deceased died at an old age (Lawuyi 1988:372). Opoku taught that, in Africa, life is not perceived as the opposite of death just as death is not the opposite of life, but death is perceived as a continuation of life in a different existence. Opoku (1989) adds the following:

The dead have an independent existence. They do not continue to live merely because they are remembered by those who are living, for the fact of life and non-life is not dependent on the memory of human beings, for human memory does not create life. (p. 19)

In the African tradition, God or the gods did not create life only to end it when the body ceases to function and that is why death and immortality are regarded as inseparable concepts (Booth 1987:158). The original intention of God or the gods who created humans were to give humans immortality, resurrection and the ability to become young again and that is why death could be regarded as a transition (Mbiti 1977:110). Furthermore, Africans teach that the living is expected to live for a period of time on earth before they are allowed to exist in a supreme form through death. The Yorubas, for example, believe that the ancestors are charged with the responsibility of overseeing that the living live out their life span as allotted to them by the gods (Eades 1980:122). Opoku (1989) sums it up when he notes that death is a stage of life:

The terms 'this life,' 'next life,' 'afterlife,' 'eternal life' are terms borrowed from European Christian philosophies [philosophy] which are foreign to African system of thought. Life is one continuous stretch of existence and is not split up into 'this life' and 'the next life.' What happens after death is not the terminal, definitive stage of man's life; it is only a phase in the continuing round of human existence ... The spirit land is not a place of eternal repose and happiness. It is rather a transit camp for those awaiting reincarnation to continue the life cycle. (p. 22)

The belief that the dead continues to live is what made Africans to undertake extravagant burial rituals after the demise of their loved ones, especially when the deceased is wealthy (Mbiti 1977:110-111). For example, the tomb of Kea in Egypt gives evidence of people who were loyal to the king and were buried alongside the king together with other expensive objects (Spronk 1986:57-58). In summary, Africans believe that the dead live amongst the living not only because they are being remembered or certain rituals are done in their honour. Rather, they believe that the dead are truly and visibly part of the living:

The deceased are truly members of the families on earth; but they are no longer of the same fleshy order as those who are still actually living on earth. They are closely related to this world; 
but are no longer ordinary mortals. Because they have crossed the borderland between this world and the supersensible world, entering and living in the latter, they have become freed from the restrictions imposed by the physical world. They can now come to abide with their folk on earth invisibly, to aid or hinder them, to promote prosperity or cause adversity. (Awolalu 1979:63-64)

The quote above suggests that the African perception of death is relevant to the understanding of their conceptualisation of NDE.

\section{Near-death experience The scientific perspective}

A formal or perhaps scientific study of the phenomenon of NDE started in the 19th century when Albert von St. Gallen Heim, a Swiss geologist, wrote about his experiences after falling from a mountain and entering into a state of coma where he had an experience of death. Afterwards, Heim also collected information from people who had similar experiences of death (Corazza 2008:24-26). An Italian psychical researcher, Ernesto Bozzano (1862-1943), did not experience NDE, but he interviewed people who observed those that had had an experience of death. Bozzano proposed that there is an 'etheric body' that survives somatic death. Johan Christophe Hampe, a German Lutheran minister, also collected information on the experiences of dying people and the victims of different accidents. He came to believe in the dual existence of the human body through which one part of it apparently survives after bodily death (Hampe 1979: 33-48). Moody (1975) proposes the name near-death experience in order to describe a situation whereby the mind leaves the body in an experience of death, yet the mind returns to the body after a period of time:

Let us, therefore, hypothesize that death is the separation of the mind from the body, and that the mind does pass into other realms of existence at this point. It would follow that there exists some mechanism whereby the soul or mind is released upon death. One has no basis upon which to assume, though, that this mechanism works exactly in accordance with what we have in our era somewhat arbitrarily taken to be the point of no return. (pp. 200-203)

Dr Raymond Moody, a philosopher-psychiatrist, interviewed 150 people who had, through various means, come close to death. Moody argues that some of his percipients were declared clinically death, yet they were resuscitated. This means that they had gone through a near-death experience. In his first book, he wrote about people who had had simple and pleasant NDEs whilst in his second book, Reflection on life after life, he cited examples of people who had had negative NDEs (Ma'SU'mian 1996:121; Moody 1975:164-200). Moody preferred to describe his percipients as people who did not die but have come close to death, hence the name NDE (Moody 1975:240).

The main reason why it is not accepted that NDE percipients have truly died is because scientists believe that anyone who came back to life in the physical form to share his or her experiences did not truly die but may have had an experience of death. Fox (2003) puts it as follows:

The person once dangerously ill, examined by Moody and now by many others, perhaps experienced dying, but certainly not death. Consequently, dying and death must be clearly distinguished. Dying means the physico-psychological [it is at this stage that one might go through the NDE] events immediately preceding death, [no possibility of NDE at this stage] which are irrevocably halted with the advent of death. Dying then is the way, death the 'destination.' And none of those [NDE percipients] investigated had reached this 'destination'. (p. 66)

A NDE is not accepted as evidence for after-life, but it allows for a revelatory encounter with death: 'whether NDEs occur in the grip of death or only in the face of death, they may still constitute a revelatory encounter with death' (Harpur 1991:52-55; Zaleski 1986). Moody likewise does not believe that NDE entails evidence for after-life beliefs. Rather, he views it as a kind of mystical phenomenon that left him with more questions than answers (Moody 1975:240). Actually, the specific physiological and psychological stimulator behind NDE still remains unclear and somewhat of a mystery (Bremmer 2002:89) as it has been argued that the experience may not be technically induced (Ma'SU'mian 1996:123).

\section{The African perspective}

\section{The human body}

In the medical or psychological sciences, there is yet to be a conclusion on whether the mind can survive bodily death. Many scientists are of the opinion that, when the brain ceases to function, the mind will not function as both entities are matter which are absolutely subject to death and decay (Harpur 1991:96). Hick (1985:113-138) argues that there is at present no scientific evidence which clearly proves or disproves that the mind survives or does not survive bodily death, hence the subject should be left open for varied interpretations. However, in African tradition, there is a passive certainty that both the body and the soul or the mind or the spirit survive physical death. For example, the Egyptians mummified bodies to allow the soul or the $B a$ to return to the body which was assumed to be a normal body and to enable the deceased successfully to journey through the dangerous parts of the otherworld at night. Egyptians glorified mummified bodies as Sah (Spronk 1986:90, 93). They believed that the soul, after bodily death, flew to the otherworld in the daytime, and with the help of Re (the Sun-god), the soul returned to the tomb at night to meet its embalmed body (Schwantes 1969:65). They served the dead with food and water because they thought that the $\mathrm{Ka}$ needed to be fed during the after-life journeys (James 1976:156). The Egyptians associated the Akh with the heart and judgement in the after-life (Parrinder 1951:203-204).

The Yorubas believe that there are five constituent parts of the human body. These are (1) Ara or physical body and 
(2) $O k a(n)$ or heart or heart-soul (The Oka(n) possesses both material and spiritual qualities. It is grouped under material constituents of the human body because of its uniqueness of possessing both characteristics). The spiritual consists of (3) Ojiji or shadow, (4) Iye or mental mind or mental body and (5) Emi(n) or spiritual body or spiritual soul. Lucas (1948: 259-260) thinks that the Egyptian word for the physical body that decays is Khat, and the Yorubas call the same physical body Ara, meaning that which belongs to $R a$. This means that both the Yorubas and the Egyptians regard their bodies as the property of $R a$ or Re the Egyptian sun-god (Lucas 1948:259-260). More so, both Ellis (1966:127) and Lucas (1948: 259-260) say that the Yoruba $O k a(n)$ means the heart. The Yorubas generally refer to the heart as $k a$ (Lucas 1948: 259-260), and the Egyptians also referred to the heart as $\mathrm{Ka}$ (Bernstein 1993:13). Lucas (1948) added that the entity Ka, as perceived by both the Egyptians and the Yorubas, is relevant to life on earth and in the after-life:

It seems, then, best to regard the $K a$ as an ancestral emanation, which was associated with each man from birth and by its superiority would guide and help him through this life and the next. (p. 263)

After the death of the body, it is expected that the $O k a(n)$ or heart-soul continues to be fed and well taken care of by the bereaved members of the family (Lucas 1948:247, 253-254).

Lucas (1948:260) equates the function of the Egyptian Khaibit [Shadow] or akh with the Yoruba Ojiji [Shadow]. The Yoruba Ojiji is viewed as an external entity which dies after bodily death, but the Egyptian Khaibit is viewed as an internal entity that is connected to the heart-soul, hence it does not perish. Both the ancient Egyptians and the Yorubas believed that the $a k h$ or Ojiji are shadows or shadow-like entities, the difference being that the akh continues to exist after bodily death whilst the Ojiji ends at death. One striking difference is that, although the Egyptian Khaibit may require food, water and other funerary offerings in order to gain strength for its after-life journey (Parrinder 1951:204), the Yoruba Ojiji does not require any funerary offering because its function is less concerned with the after-life. The Emi(n) is another important constituent part of the human body which does not die but leaves the body after bodily death (Lucas 1948:248). Emi(n) is associated with breath. It is not breath itself but that which activates breath (Idowu 1962:169). References from both the Yoruba and the ancient Egyptian concepts of the body indicate that, to an African, both the physical body and certain ethereal parts of the human body would survive death. These beliefs concerning the various divisions of the human body suggest that it would have been easier for an African to understand NDE as a natural phenomenon which involves the death of human beings and where the soul or mind of the deceased visits the world of the dead whilst living alongside the living. As the gods have powers to coordinate the activities of the human body and the soul, an African would easily regard NDE percipients as people who have truly died. Further explanations for this can be envisaged concerning the ideas of the coherence of NDE.

\section{The coherence of near-death experience from an African perspective}

There are specific features that are universal in reports concerning NDE, and the interpretation of such coherence differs depending on the percipients' culture, profession or religion (Fox 2003:86, 88-89). Percipients of NDE do claim that they saw themselves as rising through the heavens. On rising through the heavens, percipients say they saw themselves moving with another kind of spiritual body, leaving behind the physical body. This movement or passing is said to take place through a tunnel that rises up above the earth. Inside the tunnel, darkness is experienced for a very short time before arriving at the end of the tunnel which is full of light (Ma'SU'mian 1996:126). In some cultures, especially non-Western cultures, there is often no tunnel passage but a similar passage through an object or space with which the people are most familiar (Kellehear 1996:6-8).

The Yorubas believe that there is a long journey that awaits all the dead (Awolalu 1979:57). They think that heaven is located up in the sky (Ade 2006:12). The Egyptians also believed that heaven was located in the east, a place where the sun rises every day, and they associated heaven with the morning star (Spronk 1986:89). Considering the fact that these Africans believe that heaven is located in the sky suggest that, to them, death involves rising through the heavens. Another core element of NDE is passage into another realm through a border. Some say the border is a body of water, a fence, a door or a cloudy matter (Moody 1975:93). The Yorubas regard these kinds of border as a river or a mountain that the deceased is expected to cross or climb. They believe that a ferry man has to be paid in order to allow the deceased to pass through these borders (Awolalu 1979:57-58).

Percipients of NDE believe that they do meet with others during their death experiences. These are often spiritual beings like angels that might be guiding, directing, leading and giving answers to difficult questions. Sometimes, they might meet those with whom they have been familiar in life before death (Moody 1975:73-75). The Yorubas think that anyone who is declared dead can meet with other family members in the world of the dead (Ellis 1966:139-140). They also believe that there are supreme beings in heaven and in the world of the dead (Ade 2006:12). Awolalu (1979) makes the following point:

It is believed that the new ancestors will see the old and that there will be a reunion; this is why the living sends messages to the former ancestors. The Yorùbá provide food for their departed ancestors and they make sure they make regular offerings at their graves ... (p. 57)

Another popular feature of NDE reports is encountering a Being of Light said to be full of love. Various religions have different interpretations as to the concept of the Light (Corazza 2008:38-39; Moody 1975:73-75). Africans believe that there are supreme beings in heaven or on the way to heaven, and they revere these supreme beings. The Egyptians, for example, believed that Osiris is the god of the dead and the chief judge in the after-life and that Re helped the deceased during their 
journeys in the after-life (James 1976:156). They believed that the sun god crossed the heavens in a boat daily during the daytime and that he sojourned in the underworld at nighttime, carrying the souls of the dead with him (Spronk 1986:88). They also believed that, after death, the souls of the deceased associated themselves or became one with the circumpolar stars which do not set. The association of the soul with Osiris, the sun and with the circumpolar stars could be a symbolic representation of eternity (Jordan 1976:145; Murnane 1992:36) and an association with beings of light.

Most people who have a near-death experience report coming to a point where they have to give their life review. Sometimes percipients claim that they have seen the highlights of their life reviewed within a short period of time in the presence or absence of a Being of Light. The aim of this life review is to influence greater love for humanity and to create a sense of repentance for the percipients of NDE (Ma'SU'mian 1996:125-126; Moody 1975:80-81). Africans believe that judgment could be associated with death and the after-life. A typical example of the court-room judgment can be cited in the judgment of Ani and his wife Tutu. Their judgment took place in the Hall Court of judgment called Ma at (James 1976:157). The word Ma at could sometimes be associated with the maintenance of natural order, as it was expected by $\operatorname{Re}$ (Watson 2010:4), but in this case, it refers to a court-room as used by some authors (James 1976:157). In general, the word ma at seems to have been used in the cult of Osiris, and it refers to the positive standard for judgment or the standard for truth (Bernstein 1993:12). Ani stood before Osiris, and his heart was evaluated by the 42 evaluators. Anubis (the jackal-god of the necropolis), who was in charge of the scale, watched over the procession of the judgment, and Thoth (the Ibis-headed-god) took and kept records of the events concerning the judgment of Ani. In response to each of the evaluators, the deceased (Ani) denied committing any sin until he was finally declared a true voice, that is, without guilt. Ani achieved the Osirian resurrection and was finally led to meet with Osiris (James 1976:157). Also, Yoruba tradition teaches that, in the after-life, every sinner will be punished, and so, people are encouraged not to be wicked or liars during their lifetime (Idowu 1962: 197-198). The difference between NDE and the African beliefs concerning life review or a supposed judgment lies in the fact that the NDE de-emphasises the idea of punishment in the afterlife (Grey 1985:56-58). Hampe assumes that negative or hell-like NDEs are not aimed at utterly condemning the percipient but at releasing one from guilt, a form of judgment with a 'liberating and redeeming character'. He adds that, sometimes, percipients also observe themselves as spectators during the process of life review (Hampe 1979:50-51).

The NDE conception of life review is what often makes NDE percipients appreciate life more after their experiences, and that is why spiritual or philosophical transformation is one of the core features of NDE. Percipients of NDE often become more concerned about loving others, they attach more value to life after their experience, and they have less regard for the mundane pleasures of the world. Others tend to dedicate their lives to preaching about the impact of their experiences, trying to persuade people to change their ways and live for the course of justice, service to humanity and service to a divine being (Moody 1975:118-121). Africans believe that an experience with the gods, especially in the after-life, encourages purity of heart together with spiritual transformation, based on instructions received from the gods who are thought to be living for the goodness or wellbeing of all humanity. An experience of being dead is another core feature of NDE, and percipients of NDE argue beyond any doubt that they have truly died (Kellehear 1996:13-15).

Some scholars are of the opinion that the coherence in NDE is mere imagination, which is influenced by an individual's knowledge concerning the tales of ancient otherworld journeys. These tales or values which are ingrained in a person's life or soul have the ability to survive bodily death and be recalled during death experiences. Scholars such as Fox (2003) think that the core features of NDE entail the following:

[They] may prove nothing about human prospects for continued existence after death ... they do provide, at the least, a narrative pledge that our animating values have an enduring reality which is not going to be taken away by death ... a vesperal quality ... first sighting of death rather than a direct experience of it. (pp. 89-90)

However, this is not the case with Africans. African beliefs concerning death and the after-life support the core or coherence of NDE as possible characteristics of death. African thoughts on the activities of mediums, sorcerers and ancestors suggest that contact with the dead may be induced strictly through the activities of witches, mediums, sorcerers and ancestors. NDE cores are familiar terms in African beliefs, and these terms are associated with real death. This is why percipients of NDE who confess that their experiences involve these core features of NDE as discussed (together with the fact that their physical bodies failed to function during such experiences) may rather be regarded to have truly died and returned in order to tell their stories of the after-life. Zaleski thinks that those who have had a near-death experience did not truly die but share their fantastically influenced experiences because of their various cultural backgrounds (Zaleski 1986:194). Fox (2003:92) thinks that Zaleski has little understanding on how real NDE is to its percipients and that, for NDE percipients, their experiences are not imaginative but real. Fox's views correspond with African beliefs that people who have truly experienced the NDE believe that they have truly died. Percipients of NDE who are Africans might be said to have been sent by the god or ancestors to the world in order to amend their ways or to warn others to amend their ways for the good of the gods and for the good of humanity.

\section{Conclusion}

Africans believe in the division of the body, and they think that the spiritual parts of the body and sometimes the physical body itself will survive death. During the NDE, it is generally said that the mind or spirit leaves the body, and 
this idea is not a strange or new phenomenon to Africans. Developments in parapsychology and in other psychical research at present are encouraging positive research concerning the relationship between mind, brain and body, and this kind of research has aspects that support African beliefs that the mind or spirit could operate separately from the body and may survive bodily death, yet this has not been proven. Both Harpur (1991:55) and MacGregor (1992:142) point out that recent empirical studies on death experiences have without a doubt led to more research being done on the subject of traditional-mythological beliefs in life after death. It is not surprising that people in Africa who had a near-death experience are regarded to have truly died, and this is the case with Augustine Chidozie, Daniel Ekechukwu and the blind man cited in the introductory section of this research. Their confessions are taken seriously by Africans, the reason being that Africans believe that the dead can return home as a reincarnated being, an ancestor, a supreme spiritual being and sometimes as a normal human being. The Yorubas believe that it is an honour to be reincarnated, except for the Ogbanje, who came to the world to be punished or made to amend their ways (Asakitikpi 2008:59-60). At this stage, it can be suggested that, to Africans, NDE is not just an experience that leads someone to be close to death but one that leads someone to die and to return to life after death. As a result, when counselling NDE percipients or friends or relatives of people who have had near-death experiences in Africa, the counsellor ought to counsel bearing in mind that Africans regard NDE as real death, yet, with an opportunity for the percipient to return to life as ordered by the gods or ancestors. Hampe $(1979: 99-100,102)$ also thinks that the transformative impact of NDE do help percipients to live a more valued life both physically and spiritually, hence this subject is relevant to both medicine and pastoral counselling. The most serious challenge concerning this research is the fact that the criteria for certifying death from an African perspective is under-studied, otherwise it can be suggested that the complete malfunctioning of the physical body, especially the heartbeat, would have served as an ultimate criterion for certifying death in ancient Africa. This aspect of the research requires further study.

\section{Acknowledgements Competing interests}

The author declares that he has no financial or personal relationships which may have inappropriately influenced him in writing this article.

\section{References}

Adamo, D.T., 2013, 'The African wife of Jeroboam (Ano): An African reading of 1 Kings 14:1-18', Theologia Viatorum 37(2), 71-89.

Ade, D.P., 2006, 'Change and continuity: The Yoruba belief in life after death,' lecture at the Metaxus Institute Philadelphia, 03-07 June, pp. 1-15, viewed 29 May 2013 from http://www.scripd.com/doc5906776/Dopa-Mu

Agai, J.M., 2013, 'An investigation into the ancient Egyptian cultural influences on the Yorubas of Nigeria,' HTS Teologiese Studies/Theological Studies 69(1), Art. \#1919, 9 pages. http://dx.doi.org/10.4102/hts.v69i1.1919
Asakitikpi, E.A., 2008, 'Born to die: The Ogbanje phenomenon and its implication on childhood mortality in southern Nigeria,' Anthropologist 10(1), 59-63.

Awolalu, O.F., 1979, Yoruba beliefs and sacrificial rites, Longman Group Limited, London.

Bernstein, E.A., 1993, The formation of hell: Death and retribution in the ancient and early Christian worlds, Cornell University Press, Ithaca, IL.

Booth, N., 1987, 'African religions,' in P.R. Beaver, J. Bergman, M.S. Langley et al. (eds.), Eerdmans' handbook to the world religions, pp. 157-160, Wm. B. Eerdmans, Grand Rapids, MI.

Bremmer, N.J., 2002, The rise and fall of the afterlife: The 1995 Read-Tuckwell lectures at the University of Bristol, Routledge, New York, NY. http://dx.doi. org/10.4324/9780203163665

Corazza, O., 2008, Near-death experiences: Exploring the mind-body connection, Routledge, New York, NY.

De Ruiter, T.J., 2001, 'Death person return to life - Nigeria. 2 Dec,' viewed 19 June 2008, from http://home.tiscali.nl/tdruitersRM65.HTM

Eades, J.S., 1980, The Yoruba today, Cambridge University Press, Cambridge.

Ellis, A.B., 1966, The Yoruba-speaking peoples of the slave coast of West Africa, their religion, manners, customs, laws, language, etc., Anthropological, Oosterhout.

Fox, M., 2003, Religion, spirituality and the near-death experience, Routledge, New York, NY.

Grey, M., 1985, Return from death: An exploration of the near-death experience, Arkana, New York, NY.

Grosso, M., 1989, 'A postmodern mythology on death,' in A. Berger \& P. Badham (eds.), Perspectives on death and dying, pp. 232-242, Charles, Philadelphia, PA.

Halsey, D.W. \& Johnston, B. (eds.), 1989, 'Death and dying,' Collier's Encyclopedia 7(24), P.F. Collier, New York, NY, p. 758.

Hampe, J.C., 1979, To die is gain: The experiences of one's own death, Longman \& Todd, London.

Harpur, T., 1991, Life after death, McClelland \& Stewart, Ontario.

Hick, J., 1985, Death and eternal life, Macmillan, London.

Idowu, E.B., 1962, Olódúmarè: God in Yoruba belief, Longmans Press, London.

James, T.G.H., 1976, An introduction to ancient Egypt, Harper and Row, New York, NY.

Johnson, S., 2001, The history of the Yorubas: From the earliest times to the beginning of the British protectorate, CSS, Abuja.

Jordan, P., 1976, Egypt the black land, Phaidon, Oxford.

Kellehear, A., 1996, Experiences near death: Beyond medicine and religion, Oxford University Press, New York, NY.

Lawuyi, B.O., 1988 'Obituary and ancestral worship: Analysis of a contemporary cultural form in Nigeria,' Sociological Analysis 48(4), 372-379.

Lucas, J.O., 1948, The religion of the Yorubas: Being an account of the religious beliefs and practice of the Yoruba peoples of southern Nigeria, especially in relation to the religion of ancient Egypt, C.M.S. Bookshop, Lagos.

MacGregor, G., 1992, Images of the afterlife, Paragon, New York, NY.

Ma'SU'mian, F., 1996, Life after death: A study of the afterlife in world religions, Oneworld, Oxford.

Mbiti, S.J., 1977, Introduction to African religion, Heinemann, Ibadan.

Moody, A., 1975, Life after life, G.K. Hall, Boston, MA.

Murnane, W.J., 1992, 'Taking it with you: The problem of death and afterlife in ancient Egypt,' in H. Obayashi (ed.), in Death and afterlife: Perspectives of world religions, pp. 35-48, Greenwood Press, New York, NY.

Opoku, A.K., 1989, 'African perspectives on death and dying', in A. Berger \& P. Badham (eds.), Perspectives on death and dying, pp. 14-22, Charles, Philadelphia, PA.

Otey, T., 2004, 'Ancient Egyptian funerary customs', viewed 09 June 2008, from http:// www.charlotte.nc.us/History/Egypt/04/otey/htm

Parrinder, G., 1951, West African psychology: A comparative study of psychological and religious thought, Butterworth, London.

Parrinder, G., 1967, African mythology, The Hamlyn Publishing Group, London.

Schwantes, J.S., 1969, A short history of the Ancient Near East, Cushing-Mulloy, Grand Rapids, MI.

Small, A. (ed.), 1977, The concise encyclopedia of psychology and psychiatry, Franklin Watts, New York, NY.

Spronk, V.K., 1986, Beatific afterlife in ancient Israel and in the Ancient Near East, Neukirchen-Vluyn, Butzon.

Trueblood, D.E., 1963, General philosophy, Harper and Row, New York, NY.

Turner, K.A., 1993, The history of hell, Harcourt Brace, New York, NY.

Watson, J., 2010, 'The hell of ancient Egypt,' in Tour Egypt, viewed 19 May 2010, from http://www.touregypt.net/featurestories/hell.htm

Umoh, S.M., 1971, 'Nigeria's multi-ethno-cultural communications system and its influence upon social and business behaviour', PhD Dissertation, Dept. of Communications, United State International University.

Zaleski, C., 1986, Otherworld journeys: Accounts of the near-death experience in medieval and modern times, Oxford University Press, Oxford. 